\title{
Effect of Loci-Kit Models on Students' Academic Performance in Technical Drawing in Edo State Technical Colleges, Nigeria
}

\author{
Jane Itohan Oviawe*, Patrick S.O. Uddin \\ ${ }^{1}$ Department of Vocational and Technical Education Ambrose Alli University, \\ Ekpoma, Edo State, Nigeria \\ *Corresponding author, e-mail: janeoviawe@aauekpoma.edu.ng
}

\begin{abstract}
The study investigated the effect of loci-kit models on students' academic performance in technical drawing in Edo State technical colleges using non-equivalent control group quasi-experimental research design. Two research questions and two null hypotheses guided the study. The population for this study consisted of 864 vocational II students from the six technical colleges in Edo State. The sample for the study comprised of 110 (60 males and 50 females) randomly selected from all the technical colleges in Edo State. The instrument for data collection was Technical Drawing Achievement Test (TDAT). Three experts validated the instrument. The reliability of the instrument was determined using Kuder Richardson $21\left(\mathrm{~K}_{\mathrm{R}-21}\right)$ formulae and a reliability coefficient of .85 was obtained. The research questions were answered using Mean and standard deviation while Analysis of Covariance (ANCOVA) was used to test the hypotheses at .05 level of significance. Findings from the study revealed that Loci-kit model was effective in enhancing technical college students' performance in technical drawing topic loci; there was no significant mean effect of gender on students' Mean performance score in Technical Drawing. In line with the findings of the study, it was recommended among others that Technical Drawing teachers should employ innovative approaches such as loci-kit models during instructions of loci concepts in technical drawing to facilitate students' academic performance in the subject.
\end{abstract}

Keywords: academic performance, loci-kit models, technical colleges.

How to Cite: Oviawe, J. I. \& Uddin, P. S. O. (2020). Effect of Loci-Kit Models on Students' Academic Performance in Technical Drawing in Edo State Technical Colleges, Nigeria. Journal of Vocational Education Studies, 3(2), 71-84. DOI: https://doi.org/10.12928/joves.v3i2. 3201.

\section{INTRODUCTION}

Technical Vocational Education and Training (TVET) is an integral part of educational system responsible for the production of low-level manpower such as (skilled labour), craftsmen and master craftsmen. The Federal Republic of Nigeria (FRN) (2014) defined TVET as that aspect of education which leads to the acquisition of practical and applied skills as well as basic scientific knowledge. TVET is designed to prepare students for industry, agriculture, business, commerce, and home economics. To UNESCO (2015), TVET comprises education, training and skill development relating to a wide range of occupational field, production, services and livelihood. It is part of lifelong learning that can take place secondary technical colleges inclusive, post secondary and tertiary levels and include work-base learning, continuous training and development. The FRN (2014) in her national policy on education shows the levels of TVET as follows: pre-vocational education at the junior secondary school level, vocational education at the senior secondary school and technical college levels, technical education at the polytechnic and colleges of technology, TVET teacher education at colleges of education and university level.

Vocational education is prepares recipients for employment in the world of work by exposing them to practice which provide manipulative, cognitive and attitudinal skills that make these recipients qualify for employment. It is aimed at training and re-training recipients in the domains of manipulative (psychomotor), informational (cognitive), and attitudinal (affective) skills by exposing them to experiences of the real world of works. 
These domains of skill acquisition are fundamental for development and progress of individuals in within a given occupation.

Technical college is one of the institutions established by the Federal Republic of Nigeria to provide practical skills, basic scientific knowledge and attitude to individuals in order for them to live successfully in the ever-dynamic workplace. Technical college provides technical training in a number of courses which include general education, technological/engineering courses (automobile trade, building and woodwork trade, business trade, computer trade, electrical/electronics trade, mechanical trade) hospitality trade, printing trade, and textile trade (FRN, 2014). The engineering courses or trades have general education and technical drawing as a common and core subject which must be offered by technical students.

Technical drawing is the most popular, skill-oriented technical subject in any technical education programme be it at the Universities, Polytechnics, Colleges of Education (Technical), technical colleges or secondary schools (Oviawe \& Adeola, 2017) that covers work done by architects, engineers, interior designers and electricians, technical drafters, craftsmen and technical teacher educators and students. It is basically the general and explicit language of technology used by architects, engineers, technologists, designers, craftsmen, operators, manufacturers and industrialists to commune ideas by means of pictures, drawings, graphics and symbols. It is a means for communicating facts and ideas between designers and the manufacturers to bring ideas into reality by means of drafting. Technical drawing is important for the cognitive, critical and analytical skills of the brain. It sharpens the critical thinking skills of the students and enables them to solve real life problems logically as well. According to the National Board for Technical Education (NBTE) (2008) its objectives are to: (i) use and care for the different drawing instruments, equipment and materials; (ii) understand and interpret the essentials of graphical communication; (iii) illustrate the construction of simple geometric figures and shapes; (iv) demonstrate the construction of isometric and oblique drawings and productions; (v) understand the principles of orthographic projection; and (vi) explain the intersection of regular solid.

Technical drawing is a core subject for all technology and engineering based subjects and programmes in technical colleges and any TVET programme. It is the major mover of all other technically related subjects that forms a picture of concept of what should be drawn before actually drawing it. Technical drawing is one subject that stimulates phobia among students which is evident in their outcome. This has added more weight to the burden of any learner in Nigeria who is not well grounded in the knowledge of technical drawing; and this has made the effective teaching and learning an issue. Effective instructional strategy is one which encourages students' active participation in the teaching and learning process which could help the students' to obtain higher achievement in school subjects.

Anyichie and Onyedike (2012) observed that poor preparation of the students due to poor teaching and dearth of facilities are considered as the main reasons for students' poor performance at public examinations. The inability of students to engage actively in the learning process tends to dispose the students to constant role learning and examination malpractice leading to their poor academic performance. Galadima and Okogbenin (2012) opined that poor quality instructional technique employed by the teachers' is one of the major causes of poor performance among students.

The instructional method employed by the teacher plays an important role in the acquisition of skills and meaningful learning. It is one the factors that make learners become passive and have less interaction with other in doing task. Lecture methods used by teachers contribute to more than $85 \%$ of the instruction in schools in which students are isolated 
from one other (Johnson, Johnson, Holubec \& Roy, 1984). Therefore, to enhance the understanding of technical drawing teachers must embrace best practices.

Best practices in technical drawing instruction are a way of doing something that is shown to generate the desired results. The following are identified as instructional strategies that could be considered to be best practices in instruction (technical drawing inclusive): (i) focus lessons on specific concepts/skills that are standards-based; (ii) differentiate instruction through flexible grouping; individualizing lessons, compacting, using tiered assignments and varying question levels; (iii) ensure that instructional activities are learner-centred and emphasize inquiry/problem-solving; (iv) use experience and prior knowledge as a basis for building new knowledge; (v) use co-operative learning strategies and make-like connections; (vi) use scaffolding to make connections to concepts, procedures, and understanding; (vii) ask probing questions which require students to justify their responses; (viii) emphasize the development of basis computational skills (Education Alliance, 2006). Researchers (National Centre for Educational Achievement (NCEA), 2009; Oviawe, Ezeji \& Uwameiye, 2015) found that it is important for teachers to create classrooms that foster good and conductive environment where students feel relax to answer questions, make presentations, perform experiments. From the statements above, it may be argued that the teaching of technical drawing requires practices that will provide opportunities for students to find relevance and connections with what they are learning; develop interest for learning technical drawing and become lifelong learners, demonstrate positive attitude, develop relevant skills and abilities to be successful in schools and in life. Achieving all these will require the adoption of best practices in technical drawing instruction. The use of effective teaching strategy in the classroom is a key forecaster of students' academic performance (Oviawe, 2008). To this end, Oteze (2011) suggested that teaching should be structured such that knowledge is built on a foundation already possessed; encourage students to learn by doing; ensures that learning grows out of useful experiences and experimentation by effective use of manipulative that stimulate cognitive, affective and psychomotor domains' development. Iji, Abakpa and Takor (2013) posited that it is worthy of note that no pattern of curriculum implementation can be effectively without instructional materials to present various concepts. The use of manipulative in teaching and learning technical drawing concepts, shifts the process from teacher-centred approach to student activity-centred. The call for the use of best practices in Nigerian education support the use of such manipulative as the Loci-kit models in teaching and learning technical drawing.

Loci-kit models as manipulative are a set of tools or equipment that provides models of variables and integers than one uses for a particular purpose. Loci-kit models are a collection of models that are joined together for instructing and demonstrating the concepts of Loci. The Loci-kit models that were joined together are: a model of wall clock; model of a see-saw; model of paint brush representing a line; a model of tracing tray where volumes were traced; model of a goat tethered in a grazing field; model wheel of bicycle. The Loci-kit models also constituted the following models which were not joined together: Loci demonstration box, where various loci are drawn; models of surfaces that traces volume; model of intersecting chords; model of a tip of a minute hand; model of an arm of a minute hand; model of a tip of a see-saw; model of an arm of a see-saw; model of a solid set square; model of a solid protractor; models of biscuit shape tracer; model of a farm; mark pens; clay; mark pen ink; protective gloves to avoid ink contact; and chalkboard geometrical set. They are used to build concrete representations of abstract concepts. According to Sharp (1995) in Nwoke and Akukwe (2015), concrete representation of abstract ideas offer opportunities for creation of situation to facilitate translation between manipulation of concrete examples and real objects. Larbi and Okyere (2014) posited that the use of manipulative in teaching and learning holds the promise that it arouses and sustains learners' interest in an activity, ensures active participation of learners and enhances students' learning. Ado (2012) 
making declaration about manipulatives asserted that it makes students' think and discover ideas and facilitate creative thinking. They motivate the students' and provide a means of making independent investigation by the students on the concepts being taught in the class and also enhance retention.

According to Robert and Glenn (1992), Locus is a Latin word which means 'place'. A locus of points is a set of points, and only those points that satisfy given conditions. A locus can be a straight line, curved line, area or region in two dimensions or a volume in three dimensions (Kibui \& Macrae, 2005). KIE (2005) posited that locus is a path, an area or volume traced by point, line or an area that satisfy given conditions. Examples of loci include the following: (i) the locus of points a given distance from a fixed line traces, two parallel lines in two dimensions and a cylinder in three dimensions; and (ii) the locus of points a given distance from a fixed point traces a set of points describing a circle in two dimensions and a sphere in three dimensions.

Loci as a topic in technical drawing cover the following sub-topics in geometry, constructing angles, bisecting angles, constructing parallel lines, constructing perpendicular lines to given straight lines. Locus of points at a given distance from a fixed point; angle bisector locus, constant angle locus, loci of chord, inequalities; circumscribed, inscribed and described circles; and application of loci to solution of problems (K.I.E., 2002; 2005; Kinyua, Maina \& Ondera, 2005). Salmon (2009) suggested the use of relevant concrete materials in the teaching of technical drawing in which students participate and interact with models and manipulates in order to promote meaningful understanding of technical drawing concepts among students. Researchers (Elswick, 1995) have reported the importance of using concrete models in instructions in schools. These studies reveal that the use of concrete models instils in learners the confidence to think, communicate and also develop vital learning skills. Unamba and Obasi (2014) conducted a study on students' perception of $5 \mathrm{E}$ learning cycle model in mathematics learning environment and reported that students perceived $5 \mathrm{E}$ learning cycle model as mostly interactive and the model helped them understand the concept taught in mathematics. Goldsby (2009) studied the impact of a concrete, semi-concrete and abstract teaching sequence using manipulative with three students with learning disabilities and reported that the students improved in their representation and solution abilities with word problems. Students' will not gain ideas through manipulative without the teacher who takes charge of the learning process. Wodd, Cobb and Yachel (1995) asserted that learning through the use of manipulative can be successfully orchestrated by the teacher who creates the appropriate environment and who coordinates these activities with similar appropriate linguistic acquisition. To Chandran (2004), visual communication is the most effective way of communication. It is important when a concrete model or real object is used for demonstration during technical drawing teaching and learning as the teacher works through an example, verbalizes the procedure and then leaves the model for the class to refer to it towards enhancing academic performance

Performance refers to the level of individual's attainment of learning tasks. It is a measure of how much a person has accomplished after a course of instruction or training. In the school setting, students' academic performance is often determined by the learners' scores in relation to a given standard or sometimes in relation to the performance of other students in class tests, tasks, or examinations. In the context of this study, academic performance means

gender originated in objective biological divergences, goes far beyond physiological and biological specifics of the two sees in terms of the roles which they are expected to play. Gender differences unlike the immutable characteristics of sex are universally conceded in historical and comparative social analysis to be variants that are transformed over time and from one culture to the next, as societies change and evolve. Gender differences are social 
constructs, inculcated on the basis of specific society's particular perceptions of the physical differences and the assumed tastes, tendencies and capabilities of men and women (Adler, Killess \& Adler, 1992 in Oviawe, 2008). Kelly (2000) in Nwoke and Akukwe (2015) observed that there are contestable problem when attempting to relate specific intellectual abilities performance in specific subject areas, and noted sex differences and intellectual abilities can be a result of sex stereotype. Researchers have expressed diverse views about gender and academic performance especially in science and technology. To this end, Okwo and Otunbar (2007) stated that male students do better than female students; while Ogunleye and Babajide (2011) opined that performance is a factor dependent on several factors such as socio-economic background, teaching method, among others. Black (2003) documented that sex is a strong predictor of human conduct and that there are many differences between males and females in behaviour and performance. The author noted that instructional performance differs between boys and girls in school subjects. Hence, this study sought to investigate the application of loci-kit models on students' academic performance in technical drawing.

\section{Statement of the Problem}

The falling standard of education manifested in the students' academic performances at various examinations is leaving researchers and stakeholders to wonder about the future and place of Nigerian education (Oteze, 2011; Nwoke, \& Akukwe, 2015; Oviawe, Ezeji, \& Uwameiye, 2015). This has been blamed on teachers' method of teaching, inadequate instructional facilities, students' lack of interest, among others. The prevailing teachercentred methods of teaching do not actively involve the students' in the learning process and seem to be responsible for their performance in examinations. This trend has invariably led to students' poor performance in school subjects such as Technical drawing which continues to record decline in students' performance as revealed from NBTE in the year 2009, 2010, 2011 and 2012. NBTE asserted that the overall performance of students' in technical drawing has been quite low with the highest mean score in technical drawing recorded as $34.67 \%, 38 \%, 40.43 \%$ and $27.78 \%$ respectively. Similarly, there have been suggestions by researchers (Oteze, 2011; Nwoke, \& Akukwe, 2015; Oviawe, Ezeji \& Uwameiye, 2015; 2016; Oviawe \& Adeola, 2017) over time on the need for the use of innovative instructional strategies in instructions. These claims seem to suggest that they are effective in fostering students' performance in school subjects. The problem of this study therefore was predicated on the need to adopt the innovative and manipulative instructional methods such as Loci-kit models to see if it could foster students' performance in technical drawing.

\section{Purpose of the Study}

The purpose of this study was to determine the effects of using Loci-Kit Models on students' academic performance in the topic loci in technical drawing. Specially, the study sought to:

1. Compare the performance scores of students taught technical drawing using Loci-kit model and those taught with the conventional teaching method.

2. Determine the effect of gender on the performance of technical drawing students' taught using Loci-kit model and those taught with the conventional teaching method.

\section{Theoretical Framework}

This study is influenced by the experiential learning theory by John Dewy. John Dewey (1938) provided the ground work of learning theories that focus on "learning through experience" or "learning by doing". Experiential learning is also referred to as learning through action, learning by doing, learning through experience, and learning through discovery and exploration, all which are clearly defined by these well-known maxims: 
What I hear, I forget. What I hear, see and repeat, I remember.

What I hear, see and question, I understand.

What I hear, see, discuss and do, I turn into my skills. What I teach to others, I own, perfect and master.

(Confucius, 450BC)

Tell me and I forget, teach me and I remember, involve me and I will learn.

(Benjamin Franklin 1750)

There is an intimate and necessary relation between the process of actual experience and education.

(John Dewey, 1938)

\section{RESEARCH METHOD}

The study employed a pre-test, post-test non-equivalent control group quasi-experimental research design in examining the effects of Loci-Kit Models on Technical drawing students performance in technical colleges in Edo State. The design was specific with non-equivalent control group and non-randomized groups. This is because intact classes consisting of male and female students were used for the different groups.

The population for the study consisted of all the 1,064 vocational II technical drawing students from the six technical colleges in Edo State, Nigeria as at 2016/2017 academic session. Vocational II students were used for the study because vocational I students were still new at the technical colleges and vocational III were about to write their final examinations, thus the students do not need any distractions. The sample for the study comprised of 110 vocational II (60 males and 50 females) students drawn from two intact classes from the six technical colleges in Edo State. Simple random sampling technique was used to select two technical colleges for the study. The two technical colleges were grouped into two groups; namely: experimental group and control group and used for this study.

The instrument and treatment package were used for data collection were the researchers developed Technical Drawing Achievement Test (TDAT); and lesson packages on loci using loci-kit model and the conventional teaching method. TDAT contains 25 -items that tested students' knowledge, comprehension, application and technical drawing skills on detailed drawings and short answers questions that were set on definition, construction of common types of loci and application of to real life based on the Technical Drawing NBTE (2008) curriculum. The technical drawing topic loci were taught to students in the experimental classes using Loci-kit models. The following specific objectives of teaching Loci were to be achieved by the students' at the end of the topic: (i) define loci (in two and three dimensions); (ii) give some of the examples of common types of loci; (iii) construct various common types of loci; (iv) apply loci to solve real life problems; while students in the control group classes were taught the same topic with the conventional teaching method. TDAT was used for pre-test and post-test.

TDAT was validated by two Technical teacher educators and an expert in Measurement and Evaluation. The reliability of TDAT was determined by administering TDAT on a trial group of intact class of 35 vocational II Technical Drawing students in a technical college within the study population but not included in the main study using testre-test method. The reliability co-efficient of .79 was obtained using Kuder Richardson's formula $21\left(\mathrm{~K}_{\mathrm{R}-21}\right)$.

\section{Experimental Procedure}

The researchers sought for permission from the Principals and cooperation of the Technical Drawing teachers in each of the technical colleges used for the study to enable them conduct the research in their technical colleges. The researchers explained the purpose of the 
research to them and requested for their assistance in conducting the experiment. The regular teachers were coached on the lesson plan and notes prepared for the experiment two weeks before commencement of the study. The class lasted for three weeks. The experiment came to an end with the post-test. Adequate control measures were taken to eliminate all the extraneous variables that would have otherwise threatened the validity of this study.

The following precautions were taken in the course of the experiment: (i) attendance was taken at the beginning of every class session so that scores of students who would have missed any of the sessions was not used during data analysis; (ii) the three groups were given equal number of treatment; (iii) to prevent the subjects from being familiar with the questions of the pre-test and post-test, the items were re-arranged; and (iv) the time allowed for the pre-test and post-test was the same.

Mean and Standard Deviation were used to answer the research questions while the hypotheses were tested with analysis of Covariance (ANCOVA) at .05 level of significance. The pre-test scores of were used as the covariates to their post-test scores. The ANCOVA served as a means of controlling the extraneous variables from dependent variables thereby dealing with the threats of initial differences across the groups; and increasing the precision of the experimental results. Acceptance and rejection of the null hypotheses depended on this alpha level and the degree of freedom in relation to the calculated F-value. Acceptance mean of achievement score was 50 per cent in this study.

\section{RESULTS AND DISCUSSION \\ Results}

Research Question 1: What is the effect of Loci-Kit models and conventional teaching method on students' Mean performance scores in technical drawing?

Table 1. Mean Performance scores of Students' taught Technical Drawing with Loci-Kit Models and those taught with the Conventional Teaching Method at Pre-test and Post-test Scores

\begin{tabular}{|c|c|c|c|c|c|c|c|}
\hline \multirow[b]{2}{*}{ Groups } & \multirow[b]{2}{*}{$\mathrm{N}$} & \multicolumn{2}{|c|}{ Pre-test } & \multicolumn{2}{|c|}{ Post-test } & \multirow{2}{*}{$\begin{array}{l}\bar{X} \text { gain } \\
\text { score }\end{array}$} & \multirow[b]{2}{*}{ Diff in $\bar{X}$} \\
\hline & & $\bar{X}_{1}$ & SD1 & $\bar{X}_{2}$ & $\mathrm{SD}_{2}$ & & \\
\hline Loci-kit Models & 40 & 31.57 & 7.73 & 51.51 & 8.64 & 20.24 & \\
\hline $\begin{array}{l}\text { Conventional Teaching } \\
\text { Method }\end{array}$ & 62 & 31.55 & 8.79 & 33.67 & 12.13 & 2.12 & 18.12 \\
\hline
\end{tabular}

Table 1 shows the mean performance scores of students taught with loci-kit Models and those taught with the conventional teaching method at pre-test and post-test. The results indicates that students' taught with loci-Kit models had a pre-test Mean performance score of 31.57 with a standard deviation of 7.73 while at post-test, their Mean performance score increased to 51.51 with a standard deviation of 8.64 showing a Mean gain of 18.12 . This gave a difference in Mean performance gain of 18.12 in favour of the experimental group (Loci-Kit Models). Also, students taught using the conventional teaching method had a pre-test Mean performance score of 31.55 and a standard deviation of 8.79 but their Mean score at post-test was still minimal at 33.67 with a standard deviation of 12.13 indicating a little mean gain of 2.12. This implies that Loci-kit model was effective in the improvement of students' academic performance in the topic loci in technical drawing.

Research Question 2: What is the effect of gender and instructional approaches on students' post-test Mean performance scores in technical drawing? 
Table 2. Post-test Mean Performance scores of Male and Female Students' taught Technical Drawing with Loci-Kit Models

\begin{tabular}{|c|c|c|c|c|c|c|}
\hline Groups & Gender & $\mathrm{N}$ & $\bar{X}$ & SD & $\begin{array}{l}\bar{X} \text { gain } \\
\text { score }\end{array}$ & $\begin{array}{c}\text { Diff in } \bar{X} \\
\text { gain }\end{array}$ \\
\hline \multirow[t]{2}{*}{ Experimental } & Male & 33 & 52.02 & 8.28 & 0.42 & 0.27 \\
\hline & Female & 7 & 51.60 & 9.12 & & \\
\hline \multirow[t]{2}{*}{ Control } & Male & 53 & 34.01 & 12.13 & 0.69 & \\
\hline & Female & 9 & 33.32 & 11.36 & & \\
\hline
\end{tabular}

Table 2 reveals the Mean performance scores of male and female students taught with loci-kit models at post-test. The results from Table 2 revealed that at post-test, the male students in the experimental group (Loci-kit model) had a Mean performance score of 52.02 with a standard deviation of 8.28 while their female counterparts had a Mean performance score of 501.6 with a standard deviation of 9.12 indicating a slight Mean difference of 27 in favour of the male students'.

Hypothesis 1: There is no significant difference in the Mean performance scores of students' taught technical drawing using Loci-Kit Models and those taught with the conventional teaching method.

Hypothesis 2: There is no significant difference in the Mean performance scores of male and female taught Technical drawing using Loci-Kit Models and those taught with the conventional teaching method.

Table 3. Analysis of Covariance (ANCOVA) for significant difference between the Mean performance scores of Students' taught with loci-kit Models and those taught with the conventional teaching method

\begin{tabular}{lccccc}
\hline \multicolumn{1}{c}{$\begin{array}{c}\text { Sources of } \\
\text { Variations }\end{array}$} & Sum of Squares & DF & $\begin{array}{c}\text { Mean } \\
\text { Square }\end{array}$ & F-value & Sig. \\
\hline Corrected model & 18358.046 & 2 & 4589.512 & 43.513 & 0.000 \\
Intercept & 24655.624 & 1 & 24655.624 & 243.079 & 0.000 \\
Pre-test & 1.197 & 1 & 1.197 & .011 & 0.915 \\
Methods & 18125.957 & 1 & 18125.957 & 172.087 & 0.000 \\
Gender & 271.802 & 1 & 271.802 & 2.580 & 0.110 \\
Method*Gender & 183.625 & 1 & 183.625 & 1.743 & 0.188 \\
Error & 22646.004 & 105 & 105.330 & & \\
Total & 460175.000 & 110 & & & \\
Corrected total & 41004.050 & 109 & & &
\end{tabular}

Significant at $\mathrm{P}<.05$

Testing hypothesis 1, Table 3 reveals that there was significant effect of instructional strategies on students' academic performance in technical drawing with calculated F-value of 172.082 with associated probability value of .000 . Since the associated probability value of .000 is less than .05 set as bench mark, the null hypothesis which stated that there is no significant difference in the Mean performance scores of students' taught technical drawing using Loci-Kit Models and those taught with the conventional teaching method is rejected. Thus, inference drawn is that, there was significant difference in the Mean achievement scores of students taught technical drawing using Loci-kit models and those exposed to the conventional teaching method with the students' taught using Loci-kit models having a higher Mean performance score in the post-test. The result shows that Locikit model resulted in an improvement of students' academic performance in technical drawing than the conventional teaching method. 
Testing hypothesis 2, Table 3 revealed no significant Mean effect of gender on students' Mean performance scores in technical drawing with calculated F-value of 2.580 with associated probability value of .110 . Since the associated probability value of .110 is greater than .05 set as bench mark, the null hypothesis which stated that there is no significant difference in the Mean performance scores of male and female taught Technical drawing using Loci-Kit Models and those taught with the conventional teaching method is retained inference drawn is that there is no significant difference in the Mean performance scores of male and female taught Technical drawing using Loci-Kit Models and those taught with the conventional teaching method.

\section{Discussion of Findings}

The findings of this study revealed that loci-kit model is more effective in enhancing students' academic performance in technical drawing. This was demonstrated through the high Mean performance gain of students' in the experimental group as against their counterparts in the control group. Testing hypothesis 1 , the findings also revealed that there was significant difference in the Mean performance scores of students taught technical drawing using Loci-kit models and those exposed to the conventional teaching method with the students' taught using Loci-kit models having a higher Mean performance score in the post-test. The findings of this study revealed that the use of concrete materials, manipulative and specifically Loci-Kit models resulted in higher students' performance than when students' learn through the conventional teaching method. This implies that Loci-Kit models were more effective in enhancing students' performance as compared to the conventional teaching method. This finding is in line with the findings of Raphael and Wahlstrom (1989) who reported that students who use manipulative in their classes usually outperform those who do not. Similarly, Chester, Davis and Reglin (1991) reported that third grade students' who were taught geometry concepts with manipulative scored significantly higher on the post-test than the group that was presented concepts using only drawings and diagrams is in line with the findings of this study. Rule and Hllagan (2006) reported that the use of manipulative that involves hands-on and minds-on activities have positive effects on improving students' academic performance to support the findings of this study. Also supporting the findings of this study, Munger (2007) reported that the experimental group taught mathematical manipulative scored significantly higher in mathematical achievement on the post-test scores than the control group. Also in accordance to the findings of this study, Ikutal, Abanyam and Onabe (2017) found that students taught with instructional materials and manipulative perform significantly better than those taught with the conventional teaching method. The findings of this study is in agreement with Akinyemi and Orukola (2014) who noted that people learn and remember $10 \%$ of what they hear, $30 \%$ of what they discuss with others and as high as $60 \%$ of what they experience directly or practice. Contrary to the findings of this study, Hougas (2003) reported that there was no significant difference in the achievement between the experimental and the control groups after using manipulative while teaching.

The findings of the study also revealed that male students' improved in their Mean performance scores like their female counterparts taught using loci-kit models as a minor gap existed between them. The results also revealed that there was no significant effect of gender on students' academic performance in technical drawing. The non-significant difference in performance observed between male and female students in technical drawing may be attributed to the effectiveness of loci-kit models. The findings of this study is in accordance with that of Hougas (2003) who reported that there is no significant difference in the achievement between the male and female students' after using manipulative while teaching. Supporting the finding of this study, Oludipe (2012); Ndinika and Ubani (2017) found no significant difference in the Mean scores of male and female students. The finding of this study contradicts that of Ibe and Nwosu (2003) who reported that girls achieved 
more than boys in science subjects, and that female learners show some superiority over male learners. This findings of Larbi and Okyere (2014); Nwoke and Akukwe (2015) who noted that when girls and boys are instructed through extensive use of manipulative, girls benefit most, which enable them to perform at almost equal level as their male counterparts contradicts the findings of this study. Asaf and Zahoo (2017) found that girls performed better than boys in their study did not support the findings of this study. Also contradicting the findings of this study is that of Ogundola (2017) who found that gender had effects on students' achievement in technical drawing in favour of girls. Barbican (2008) asserted that irrespective of the method used in teaching concepts, boys usually achieved significantly better than girls contradicts the findings of this study. The findings of this study disagree with that of Nnamani, Akabogu, Uloh-Bethel and Ede (2018) who reported that gender had effect on students' achievement in favour of the girls. Okoro (2011) asserted that male students achieve higher than their female counterparts in science. However, Thompson and Thompson (1994) reported that concrete materials are likely to be misused when a teacher has in mind that students will learn to perform some prescribed activity with them. It is important to ensure that the Loci-kit models are used properly and for sufficient time for effective and meaningful learning to occur.

\section{CONCLUSION}

The findings of this study revealed that Loci-kit models promoted students performance in technical drawing irrespective of their gender. It is concluded that in this time when there is urgent need for a sound and improved quality of education, it becomes pertinent to promote best practices in the education system in the use of manipulative such as Loci-Kit models. Based on the findings of this study, the following recommendations were made:

1. Technical drawing teachers should use innovative approaches such as Loci-kit models in teaching to foster students' interest and academic performance.

2. Technical drawing teachers should be trained and exposed to in-service training, seminars, workshops, conferences and other forms of training-on-the-job to enhance their knowledge on new wave of instructional manipulative such as loci-kit models for teaching.

3. Government and all stakeholders in the education sector should encourage technical drawing teachers through the provision of instructional materials in technical drawing studios for teaching and learning technical drawing.

4. Technical drawing studios should be established in technical colleges and other TVET institutions to enable teachers and students' to improvise and use instructional manipulative such as loci-kit models and perform technical drawing practical.

\section{REFERENCES}

Ado, M.S. (2012). Effect of teaching aids on the mathematics achievement of junior secondary school students in Zaria Local Government Area of Kaduna State. Journal of science, technology and education, 1 (1), 6-10.

Akinyemi, S.A. \& Orukola, O.E. (2014). Science and society. Ibadan: University press.

Anyichie, A.C. \& Onyedike, C.C. (2012). Effects of self-instructional learning strategy on secondary school students' academic achievement in souring mathematical word problem in Nigeria African research reviled. An international multidisciplinary journal, Ethiopia, 6 (4), 302-323.

Asaf, N. \& Zahoo, U.R. (2017). Effects of peer tutoring strategy and students success in mathematics. Journal of research and reflection in education, 11 (1), 15-30. 
Barbican, T.G. (2008). An empirical investigation to determine the relative effectiveness of discovery laboratory and exposition methods of teaching science concepts. Journal of research in science teaching, 28 (3), 201-209

Black, J.H. (2003). Debatable conclusion about sex difference. Contemporary psychology about sex difference, 21, 81-93.

Chandran, E. (2004). Research Methods. Daystar University Nairobi: Starb Right Services Ltd.

Chester, J., Davis, J. \& Reglin, G. (1991). Math manipulatives use and math achievement of third-grade students (Report No. SE-052-315). University of North Carolina at harlotte. (ERIC Document Reproduction Service No. ED339591)

Dewey, J. (1938). Experience and education. New York. NY: Macmillan Education Alliance (2006). Closing the achievement gap: Best practices in teaching mathematics. Charlestion, WV: The Education Alliance

Elswick, V.A. (1995). Using manipulative to develop understanding. Integrated mathematics teachers editions. Boston: Houghton Mifflin Company.

Federal Republic of Nigeria (2014). National policy on education. Lagos: NERDC.

Galadima, I. \& Okogbenin, A.A. (2012). The effect of mathematical games on academic performance and attitude of senior secondary school students towards mathematics in selected schools in Sokoto State. Abacus: The journal of mathematical association of Nigeria, 27 (1), 57-65.

Goldsby, D. (2009). Manipulative in middle grades mathematics. Research summary. Retrieved from http://www.amle.org/Browsebytopic/whatsnew/WNDet/Tabld/2

Hougas, L. (2003). Using manipulatives to teach fractions. A thesis presented to the Faculty of Education, Viterbo University in partial fulfilment of the requirements for the degree Master of Arts in Education: Viterbo University

Ibe, E. \& Nwosu, A.A. (2003). Effect of guided inquiry and demonstration on science process skills acquisition among biology students in secondary schools. Journal of science teachers association of Nigeria, 36 (2), 58-63.

Iji, C., Abakpa, B. \& Takor, B. Improving the teaching and learning of mathematics for the attainment of millennium development goals (MDGs) through the use of mathematics games in Makursi Local Government Area. International journal of social science and education, 4 (1), 174-185.

Ikutal, A., Abanyam, V.A. \& Onabe, M.B. (2017). Effect of the use of instructional materials on senior secondary school agricultural science students' performance in Cross River State. Journal of Association of vocational and technical educators of Nigeria (JAVTEN), 22 (1), 217-224.

Johnson, D., Johnson, R., Holubee, E. \& Roy, P. (1984). Circles of learning: Cooperation in the classroom. Alexandria VA: Association for supervision and curriculum development Kibui, P. \& Macrae, M.F. (2005). Explore mathematics. Nairobi: Longman Kenya.

KIE (2002). Secondary education syllabus, 2, Nairobi: KIE.

KIE (2005). Secondary mathematics students book four, Nairobi: KLB

Kinyua, M. Maina, L. \& Ondera, J. (2005). Advancing in mathematics teachers' guide 4, Nairobi: Longman Publishers.

Larbi, E. \& Okyere, M. (2014). Algebra tiles manipulative and gender differences in earning and achievement in mathematics: A case of Sunyani West Municipality. Journal of education and practice, 5 (38), 1-7.

Munger, D. (2007). Children learn and retain math better using manipulatives[Msg.I]. Retrieved from: http://scienceblogs.com/cognitivedaily/2007/10/children_learn_and_reatain_math. php

National Board for Technical Education (2008). Technical drawing curriculum for technical 
colleges. Kaduna: NBTE

National Business and Technical Education Board (2012). Chief Examiner's report on academic achievement in vocational and technical education. Benin City: National Business and Technical Examination Board.

National Centre for Educational Achievement (2009). Core practices in mathematics and science: An investigation of consistently higher performing schools in five states. Austin, TX: National Centre for Educational Achievement.

Ndirika, M.C. \& Ubani, C.C. (2017). Effect of peer tutoring teaching strategy and academic achievement of secondary school biology students in Umuahia education zone, Nigeria. IOSR journal of research method in education, 7 (3), 72-78.

Nnamani, P.A., Akabogu, U. J. Ulloh-Bethel, C.A. \& Ede, O.M. (2018). Effect of reciprocal peer tutoring on computer students' achievement in expository essay writing: Implication for school counselling. International journal of applied engineering research, 13 (21), 15102-15107.

Nwoke, B.I. \& Akukwe, A,C. (2015). Promoting junior secondary students' achievement in algebra using algebra tiles manipulative. International journal of educational research, $14(3), 164-170$

Ogundola, I.P. (2017). Effect of peer tutoring strategy on academic achievement of senior secondary school students in technical drawing in Nigeria. British journal of education, society and behavioural science, 19 (1), 1-10. Retrieved from http://www.sciencedomain.org.

Ogunleye, B.O. \& Babajide, V.F.T. (2011). Commitment to science and gender as determinants of students' achievement and practical skills in physics. Journal of the science teachers association of Nigeria, 46 (1), 125-135.

Okoro, A.U. (2011). Effect of interaction patterns on achievement and interest in biology among secondary schools in Enugu State, Nigeria. Unpublished M.Ed thesis, Department of Science Education, University of Nigeria, Nsukka.

Okwo, F.A. \& Otunbar, S. (2007). Influence of gender and cognitive styles on achievement of students' in physics easy test. Journal of science teachers association of Nigeria, 42 (1 \& 2), 133-138.

Oludipe, O.I. (2012). Gender difference in Nigerian junior secondary students' academic achievement in basic science. Journal of education and social science, 2 (1), 93-99.

Oteze, I.K. (2011). Mock examination as predictor of students' performance in SSCE mathematics for the attainment of millennium development goals. Abacus: The journal of the mathematical association of Nigeria, 36, 18-26.

Oviawe, J.I. (2008). Effect of peer-tutoring-assisted instruction on students' academic achievement in introductory technology. FCT Education Secretariat Journal of Curriculum Studies and Instruction 1 (1), 77 - 84.

Oviawe, J.I. \& Adeola, L. (2017). Effects of concept mapping instructional strategy on students' academic performance and interest in technical drawing in technical colleges in Edo State, Nigeria. IOSR Journal of Research and Method in Education (IOSR-JRME), 7 (3) Ver. 1 (May-June) 9-15.

Oviawe, J.I., Ezeji, S.C.O.A., \& Uwameiye, R. (2015). Comparative effectiveness of three methods on the academic performance of students in building technology in Nigerian polytechnics. European Scientific Journal 11 (12), 274-285.

Oviawe, J.I., Ezeji, S.C.O.A., \& Uwameiye, R. (2016). Effects of cooperative learning on building technology students' acquisition of workplace skills. Indian Journal of Vocational Education 20 \& 21 (1), 77-88.

Raphael, D. \& Wahlstorm, M. (1989). The influence of instructional aids on mathematics achievement. Journal for research in mathematics, 20, 173-190.

Robert, C.J. \& Glenn, J. (1992). Mathematics dictionary. Springer 
Rule, A.C. \& Hllagan, J.E. (2006). Pre-service elementary teachers' use: Drawing and makesets of materials to explain multiplication and division of fractions. ETA Production.

Russsell, C.D. (2012). Gender, academic and meanings of schooling. (A published Ph.D dissertation), Colombia University.

Salman, M.F. (2009). Activity learning techniques (ALT) in a mathematics workshop: Nigeria primary school teachers' assessment. International electronic journal of mathematics education (IJME), 41 (1), 23-35.

Thompson, P.W. \& Thompson, A.G. (1994). Talking about rates conceptually, part I: A teacher's struggle. Journal for research in mathematics education, 25 (1), 279-303.

Unamba, E.C. \& Obasi, C. (2014). Examined students' perception of 5E learning cycle model in mathematics learning environment. Journal of research and development in education (JORDE), 5 (1), 117-122.

UNESCO (2015). A handbook for TVET teachers' in Africa. Paris: UNESCO.

Wood, T., Cob, O. \& Yackel, E. (1995). From alternative epistemologies to practice in education: Rethinking what it means to teach and learn. In: Steffe, L. \& Gale, J. (Eds.). Constructivism in education. LEA: London. 
